Primljeno: 5.7.2021.

Prihvaćeno: 26.8.2021.

DOI: $10.36506 /$ av.64.4

\title{
Ana Bešlić
}

Hrvatski državni arhiv

Zagreb, Hrvatska

abeslic@arhiv.hr

\section{Andreja Dragojević}

Hrvatski državni arhiv

Zagreb, Hrvatska

adragojevic@arhiv.hr

\section{RUČNO RAĐENI PAPIR: POVIJEST, IZRADA, SVOJSTVA I VODENI ZNAKOVI}

\author{
UDK: 676.026.22:091 \\ 745.54 \\ 676
}

Pregledni rad

Članak donosi kratki pregled povijesti ručne izrade papira, od njegova izuma u Kini oko 105. godine, preko sirenja kroz arapski svijet i dolaska u Europu, pa sve do konca 18. stoljeća, kada je počela strojna proizvodnja papira. Povijest ručno radenoga papira duga je $i$ zanimljiva, od prvih pronalazaka kao zamjena za pergamentnu podlogu za pisanje pa sve do prvih strojeva za usitnjavanje papirne pulpe. Putovanje tehnologije papira kroz zemlje Azije preko arapskih zemalja do Europe trajalo je 11 stoljeća $i$ doživjelo različite tehnološke promjene. Neke od njih sačuvane su do današnjih dana kao dio tradicije izrade papira. Dolaskom u Europu tehnologija $i$ sirovina prilagodeni su ovdašnjim mogućnostima: tako su se za sirovinu počeli koristiti laneni krpeni ostatci, a kao dodatak želatina. Unaprjeđena je tehnologija, proširili su se papirni mlinovi, a potražnja za papirom bila je sve veća zbog izuma tiskarskoga stroja, sve veće produkcije knjiga i potrebe za pisanim podlogama za druge zapise. Učlanku je prikazan i povijesni razvoj vodenih znakova, od najranijih sačuvanih, jednostavnih znakova iz Cremone, na području današnje Italije, do složenijih, 
koji su se postupno javljali razvojem tehnologije. Kolekcionari vodenih znakova papira svojom skupljačkom strašćc doveli su i do razvitka pomoćne povijesne znanosti filigranologije. Danas su tomu dijelu povijesti papira posvećene čitave digitalne platforme diljem Europe, evidentirajući njihovu pojavu, koja može pomoći u datiranju papira, a ponekad i dokumenata.

Ključne riječi: papir; ručna izrada papira; svojstva ručno radenih papira; vodeni znak; kontramarka; baze vodenih znakova

\section{Uvod}

Povijest papira možemo prema načinu proizvodnje podijeliti na dva glavna razdoblja: ono ručne proizvodnje papira te razdoblje industrijske proizvodnje, koje je uslijedilo nakon njega, pri čemu sam način izrade papira, kao i izbor sirovina za njegovu izradu, uvelike određuju kvalitetu samoga papira. No koja su to svojstva po kojima se jedan razlikuje od drugoga? Iskusni konzervator restaurator već će na prvi pogled znati prepoznati ručni od industrijsko rađenoga papira, kao i kako bi se taj papir mogao ponašati tijekom konzervatorsko-restauratorskih postupaka. Onaj manje iskusan vjerojatno će potražiti daljnja obilježja koja će mu potvrditi da je uistinu riječ o ručno rađenom papiru. Preduvjet je za oboje, uz iskustvo konzervatora restauratora, poznavanje povijesti papira te načina njegove proizvodnje, što olakšava izbor konzervatorsko-restauratorskih postupaka, koje uz kemijski sastav papira određuju među ostalim stanje predmeta čiji je nositelj papir, kao i njegova povijest, o kojoj nam govore tragovi prisutni i u samom papiru. Stoga poglavlja koja slijede donose kratak prikaz povijesti ručne proizvodnje papira i širenja njegove uporabe od drevne Kine, preko arapskoga svijeta, sve do Europe, u koju je po prvi put dospio u 12. ili 13. stoljeću. U njima su opisana i svojstva ručno rađenih papira, među kojima je posebna pažnja posvećena možda onomu vizualno najzanimljivijemu: vodenim znakovima.

\section{Povijest ručne izrade papira: početci}

Povijest papira stara je gotovo dvije tisuće godine. Iako je nemoguće točno odrediti kada su nastali prvi pokušaji stvaranja nove podloge za pisanje, kao službena godina njezina začetka uzima se 105., kada ju je u drevnoj Kini caru Yungu Yuanu predstavio eunuh Ts'ai Lun. ${ }^{1}$ Prema zapisu učenjaka Fana Yeha iz 5. stoljeća, upravo je njemu prvomu sinula ideja o novoj podlozi za pisanje, načinjenoj od kore drveta, starih krpa, ribljih mreža i ostataka konoplje, a koja bi zamijenila puno skuplju svilu i nepraktične i teške bambusove pločice, koje su

1 Dard Hunter, Papermaking: The History and Technique of an Ancient Craft (New York: Dover Publications, 2014), str. 50. 
dotada nosile kineske zapise. ${ }^{2}$ Prednost papira bila je i u njegovoj bržoj proizvodnji, kao i u njegovoj lakšoj pohrani. ${ }^{3}$

Papir se je kao materijal počeo koristiti diljem carstva. Preko Koreje, koja je tada bila njegovim dijelom, a zahvaljujući budističkim redovnicima, papir je početkom 7. stoljeća dospio u Japan, koji je s njegovom proizvodnjom započeo oko 610. godine. ${ }^{4}$ Zahvaljujući redovnicima, papir je došao na područje Vijetnama i Indije, iz koje su i potjecali izvorni budistički tekstovi. ${ }^{5}$ Svilenim putem dospio je do Perzije, u čijim se je gradovima prodavao. Tu su tajnu proizvodnje papira saznali Arapi 751. godine pobijedivši u bitci na obali rijeke Talas u Turkestanu, ${ }^{6}$ kada su se među njihovim ratnim zarobljenicima našli i Kinezi upoznati $s$ tajnom proizvodnje papira. ${ }^{7}$ Uvidjevši da je riječ o materijalu puno prikladnijem za formiranje kodeksa (to jest knjiga), ${ }^{8}$ muslimanski svijet njime je zamijenio prije korišteni papirus u pisanju Kurana. ${ }^{9}$ Time je započela arapska proizvodnja papira, koja se je strjelovito proširila na tom području. Godine 794. u Bagdadu je izgrađena prva velika državna radionica papira, a iste je godine sultan Harun al Rašid uveo papir i u svoje dvorske kancelarije. Nekoliko godina kasnije proizvodnja je proširena u Damask, Tibani, Tripolis i druge gradove. ${ }^{10}$ Papir je tako stigao do Mediterana, a potom i do ostatka Europe (Slika 1), čiji najstariji rukopis napisan na papiru Breviarium et Missale mozarabicum datira iz 1036. godine, a nastao je na području današnje Španjolske. Proizvodnja papira po prvi se je put u Europi javila u 12. ili 13. stoljeću na području Italije i/ili Śpanjolske. ${ }^{11}$

\footnotetext{
2 Hunter, Papermaking, str. 52.

3 Hunter, Papermaking, str. 50

4 Hunter, Papermaking, str. 53.

5 Usp. Jonathan M. Bloom, "Papermaking: The Historical Diffusion of an Ancient Technique," u Mobilities of Knowledge, ur. Heike Jöns, Peter Meusburger i Michael Heffernan (Cham: Springer, 2017), str. 54; Hunter, Papermaking, str. 53.

6 Turkestan, povijesni naziv od 16. stoljeća za geografsko područje u srednjoj Aziji pod vlašću turkijskih naroda: sjeverni Afganistan, Turkmenistan, Uzbekistan, zapadni Kirgistan, južni Kazahstan i zapadna Kina. "Turkestan," u Hrvatska enciklopedija: 11: Tr-Ž, ur. Slaven Ravlić (Zagreb: Leksikografski zavod Miroslav Krleža, 2009), str. 112.

7 Hunter, Papermaking, str. 60.

8 Kodeks je najstariji oblik knjige. Prvo je bio diptih, zatim poliptih dvije ili više kožnom vrpcom spojenih povoštenih tablica za pisanje. Poslije se kodeksom počela nazivati knjiga pisana na pergameni ili papiru. "Kodeks," u Hrvatska enciklopedija: 6: Kn-Mak, ur. August Kovačec (Zagreb: Leksikografski zavod Miroslav Krleža, 2004), str. 22-23.

9 Martin A. Hubbe i Cindy Bowden, "Handmade Paper: A Review of Its History, Craft, and Science," BioResources 4, br. 4 (2009): str. 1736-1792.

10 Zvonimir Kulundžić, Knjiga o knjizi: Historija pisama, materijala i instrumenata za pisanje (Zagreb: Školska knjiga, 1951), str. 449.

11 Usp. Hunter, Papermaking, str. 60; Bull's Head And Mermaid: The History of Paper and Watermarks from the Middle Ages to the Modern Period, ur. Peter Rückert, Sandra Hodeček i Emanuel Wenger (Stuttgart: Hauptstaatsarchiv Stuttgart, 2009), str. 13.
} 
Do kraja 13. stoljeća papir je iz uporabe gotovo istisnuo pergamenu, izdržljiviji, no ujedno i skuplji materijal koji je do pojave papira bio dominantan u Europi, ${ }^{12}$ a koji je sa sve većom uporabom papira ostao rezerviran za one najvrjednije i politički najvažnije dokumente kao što su zakoni i povelje, preferiran zbog svoje izdržljivosti. ${ }^{13}$ Uporabi papira pogodovalo je i sve češće podizanje mlinova za proizvodnju papira diljem Europe nakon 13. stoljeća, ${ }^{14}$ kao i dva stoljeća kasnije izum tiskarskoga stroja, koji je uvelike povećao potražnju za papirom - materijalom koji se je pokazao prikladnim za tiskanje knjiga. ${ }^{15}$

Prvi kineski papiri izrađivani su od sirove ili tkane svile. Do 3. stoljeća u izradi papira počela su biti korištena i biljna vlakna, kao što su ona konoplje, bambusa, duda te raznih trava. Spomenute biljke namakale bi se $s$ ciljem omekšavanja te bi se potom ručno tukle na kamenu ili u kamenom mužaru, čime se je postizalo njihovo razvlaknjivanje. Dobivena vlakna miješana su s vodom: takva suspenzija nalijevana je na kalup s napetom tkaninom, koji se je potom ostavio sušiti na suncu formirajući list papira. Postupak izrade bio je spor i težak. ${ }^{16}$ Prvi kalupi za izradu papira bili su jednostavne izrade: tek okvir načinjen od bambusa na koji bi se nategnula grubo tkana tkanina. ${ }^{17}$ Jedna od ključnih promjena u ranoj povijesti izrade papira bio je izum kalupa koji je mogao biti uronjen u vodenu suspenziju vlakana, a $s$ kojega se je formiran list papira mogao skinuti dok je još uvijek bio vlažan. Takvi su kalupi bili načinjeni od tankih bambusovih traka međusobno povezanih svilenim ili lanenim koncem ili konjskom, devinom ili jakovom dlakom, tvoreći tako rešetku. Uranjanjem kalupa u vodenu suspenziju naspram dolijevanja vlakana na kalup izrada papira postala je puno produktivnija: omogućena je izrada većega broja listova papira koji su ujedno bili veće kvalitete. ${ }^{18}$ Upravo je papir načinjen od biljnih vlakana bio onaj koji su budistički redovnici prenijeli u Japan. ${ }^{19} \mathrm{Ti}$ istočnoazijski papiri od početka su bili namijenjeni pisanju: mekani, tanki, fleksibilni i dovoljno propusni bili su prikladni za kaligrafiju. ${ }^{20}$ Izrađeni bez keljiva, ${ }^{21}$ papiri su bili spremni za uporabu

\footnotetext{
12 Bull's Head And Mermaid, str. 13.

13 Hubbe i Bowden, "Handmade Paper," str. 1743; Bloom, "Papermaking," str. 52-54.

14 Bull's Head And Mermaid, str. 13.

15 Hunter, Papermaking, str. 170.

16 Hunter, Papermaking, str. 56, 78-79 i 139.

17 Hunter, Papermaking, str. 78.

18 Hunter, Papermaking, str. 170.

19 Hunter, Papermaking, str. 56.

20 Hunter, Papermaking, str. 61.

${ }^{21}$ Keljenje je dodavanje prikladnih tvari u postupku pripremanja papirne mase. Keljenjem papir gubi svojstvo upojnosti, postaje prikladan za pisanje tintom i za tisak oštrih kontura. Keljivo je sredstvo za keljenje papira. Prvobitno je u tu svrhu služilo koštano tutkalo, kazein, škrob i vodeno staklo. Danas se pretežno rabi smola i neke druge tvari koje imaju slične osobine, prvenstveno voskovi te neke krute masne kiseline. Franjo Mesaroš, Grafička enciklopedija (Zagreb: Tehnička knjiga, 1971), str. 115.
} 
odmah nakon sušenja, pogodni za pisanje pomoću mekanoga kista. ${ }^{22} \mathrm{Za}$ razliku od njih, Arapi, koji su se u pisanju koristili kalamusom, ${ }^{23}$ pisaljkom načinjenom od zaoštrene trske, ${ }^{24} \mathrm{u}$ proizvodnji papira počeli su koristiti i keljiva, ${ }^{25}$ preinačivši tako postupak izrade papira koji su naučili od kineskih zarobljenika. To nije bila jedina promjena koju su uveli. U nedostatku duda, koji nije uspijevao na području Perzije, Arapi su kao materijal za proizvodnju papira vjerojatno koristili lanene krpe. Slažući ih u hrpe i močeći ih vodom poticali su proces fermentacije, ubrzavajući tako njihovo raspadanje, kombinirajući ga s tradicionalnim udaranjem o kamen, nakon čega bi uslijedilo kuhanje u lužini dobivenoj od pepela drveta. Tako prokuhana masa premještana je u vreću, koju bi se podvrgnulo djelovanju tekuće vode ne bi li se isprali ostatci lužine, kao i većina još uvijek zaostale prljavštine. Uvelike su olakšali i samu proizvodnju papira počevši koristiti nagibne čekiće u usitnjavanju vlakana, čime su zamijenili težak i mukotrpan postupak udaranja vlakana rukom. ${ }^{26}$ Gotovi papiri bili bi premazani keljivom na bazi škroba, u koje bi se ponekad mogla dodati i bijela kreda. ${ }^{27}$ Uslijedilo bi poliranje papira glatkim kamenom ili staklom, čineći ga tako u potpunosti pogodnim za pisanje. ${ }^{28}$

Arapski papiri, u čijoj je proizvodnji korišten škrob, bili su prikladan materijal za pisanje u područjima suhe i tople klime, no na prostoru Europe takav je papir zbog utjecaja klimatskih uvjeta bio sklon napadu mikroorganizama i razvoju plijesni, stoga ne čudi kako je godinama nakon uvođenja papira u Europu pergamena još uvijek bila prvi izbor kada je bila riječ o pisanju važnih dokumenata. ${ }^{29}$ Valja pripomenuti da su Europljani ujedno isprva bili nepovjerljivi prema novomu materijalu koji je dolazio iz muslimanskoga svijeta. ${ }^{30}$

\footnotetext{
22 Bloom, "Papermaking," str. 62.

23 Bloom, "Papermaking," str. 62.

24 "Kalamus," u Hrvatska enciklopedija: 5: Hu-Km, ur. August Kovačec (Zagreb: Leksikografski zavod Miroslav Krleža, 2003), str. 438.

25 Bloom, "Papermaking," str. 62.

26 Hunter, Papermaking, str. 139-140.

27 Jozef Dąbrowski, "Paper Manufacture in Central and Eastern Europe Before the Introduction of Paper-making Machines," Łodź, srpanj 2008, pristupljeno 7. lipnja 2021., http://www.paperhistory. org/dabro.pdf, str. 9-10; Karen Garlick, "A Brief Review of the History of Sizing and Resizing Practices." The Book and Paper Group Annual 5 (1986): str. 98-107.

28 Bloom, "Papermaking," str. 62.

29 Usp. Bull's Head And Mermaid, str. 16; Bloom, "Papermaking," str. 62.

30 Hunter, Papermaking, str. 61.
} 


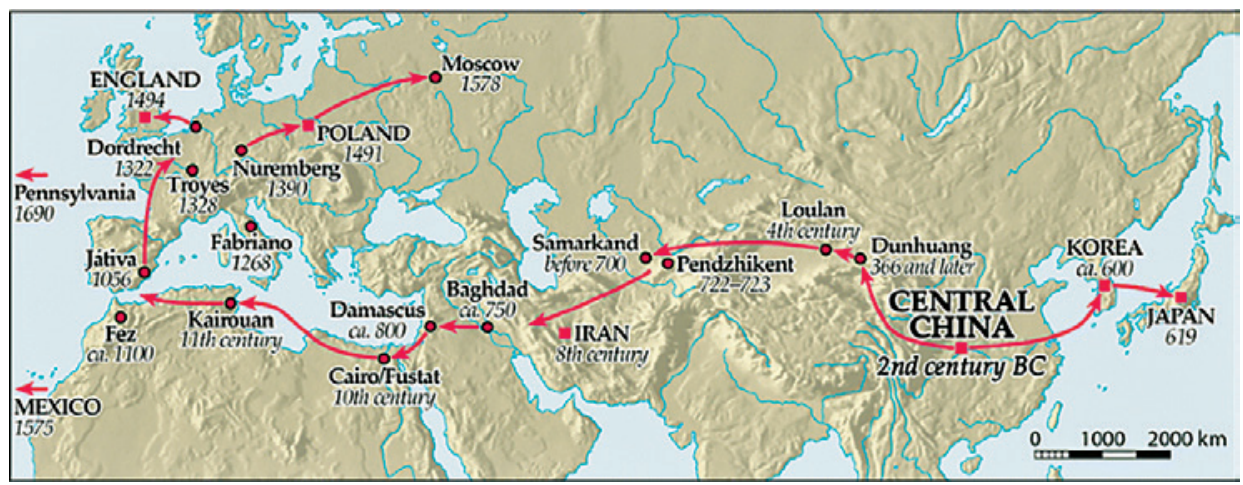

Slika 1. Prikaz sirenja izrade papira po Euroaziji. Autor: kartograf V. Schniepp (Heidelberg University, Institute of Geography)

\section{Povijest izrade papira u Europi}

Kada je papir došao u Europu nije točno poznato, no postojeći izvori govore da se je to dogodilo negdje tijekom 12. ili 13. stoljeća na Apeninskom ili Pirenejskom poluotoku (današnja Italija i Španjolska): iz zapisa Petra Časnoga, opata benediktinskoga samostana Cluny, znamo da je već u 12. stoljeću na području Pirenejskoga poluotoka korišten materijal načinjen od ostataka starih $\mathrm{krpa},{ }^{31}$ a arapski kartograf i geograf El-Edrisi ${ }^{32} \mathrm{u}$ zapisu iz 1150 . godine spominje proizvodnju papira u (španjolskom) gradu Xátivi. ${ }^{33} \mathrm{Na}$ Apeninskom poluotoku papir se je počeo rabiti 1154. godine - riječ je o papiru uvezenom s Istoka. Proizvodnja papira ondje je po prvi put zabilježena 1276. godine u Fabrianu. ${ }^{34}$ Zamah je dobila u 14. stoljeću kada se je razvila velika proizvodnja papira s nizom mlinova u Padovi, Trevisu, Bologni, Parmi, Veneciji i Milanu, čime su ti gradovi stekli prvenstvo u proizvodnji papira. U svojoj ekspanziji proizvodnja papira širila se je tijekom 14. stoljeća sa sjevera Apeninskoga poluotoka na područje današnje južne Njemačke. ${ }^{35}$ Povijesni podatci (Nürnbeška kronika) ${ }^{36}$ govore da je

31 Bloom, "Papermaking," str. 59.

32 "Idrisi," u Hrvatska enciklopedija: 5: Hu-Km, ur. August Kovačec (Zagreb: Leksikografski zavod Miroslav Krleža, 2003), str. 38.

33 Usp. Hunter, Papermaking, str. 473.

34 Usp. Hunter, Papermaking, str. 473-474.

35 Kulundžić, Knjiga o knjizi, str. 452.

36 Nürnbeška kronika ili Liber Chronicarum univerzalna je povijest koju je iz starijih i suvremenih izvora sastavio nürnberški liječnik, humanist i bibliofil Hartmann Schedel (1440.-1514.). Jedno je od najgušće ilustriranih i tehnički naprednih djela ranoga tiska. Sadrži 1.809 drvoreza izrađenih od 645 blokova. Nürnberški poduzetnik Sebald Schreyer i njegov zet Sebastian Kammermeister financirali su produkciju knjige. Michael Wolgemut i njegov zet Wilhelm Pleydenwurff ilustracije su izradili oko 1490. 
gradski patricij Ulman Stromer ${ }^{37}$ 1390. pred vratima Nürnberga podigao veliku radionicu papira. Stromer je odlučio pokrenuti papirnati mlin nakon što je prepoznao uspjeh koji je taj posao imao na Apeninskom poluotoku. ${ }^{38}$

Jedna od glavnih promjena koju je donijela europska proizvodnja papira bila je uporaba želatine kao keljiva dobivenoga iskuhavanjem životinjskih koža, papaka i kopita. Uporabom toga keljiva europski je papir ujedno postao pogodniji za pisanje perom, koje je korišteno za pisanje na pergameni: papir je time postao čvršći i mehanički otporniji. ${ }^{39} \mathrm{Ta}$ inovacija svoje podrijetlo nalazi upravo u talijanskom gradu Fabrianu, ${ }^{40}$ ćiji je papir bio izrazito cijenjen zbog svoje kvalitete. Jedan od razloga njegove finoće i bjeline bio je u kvalitetnoj i dobro razvlaknjenoj papirnoj pulpi. ${ }^{41}$ Razvlaknjivanje je provođeno pomoću tzv. pila a magli multipli, stroja koji je izvorno korišten u lokalnim radionicama vune. Prilagodbom stroja za mljevenje lanenih i konopljinih krpa, olakšan je i sam postupak proizvodnje. Inovacija koju također uvode proizvođači papira u Fabrianu bila je pojava vodenih znakova, kojima je označavana kvaliteta i podrijetlo papira. ${ }^{42}$

Postupak izrade papira tijekom srednjega vijeka u Europi tekao je u nekoliko faza. Glavni materijal koji je korišten u izradi papira bile su macerirane lanene i konopljine $\mathrm{krpe},{ }^{43}$ koje su skupljane i potom prodavane papirnim mlinovima. U početku je njihovo razvlaknjivanje započinjalo, kao kod Arapa, potpomognutim procesom truljenja: ${ }^{44}$ krpe su održavane mokrima i po šest tjedana, katkada uz dodatak vapna, ne bi li bio ubrzan proces fermentacije, nakon čega bi uslijedilo njihovo daljnje razvlaknjivanje mehaničkim putem pomoću udaranja, čime bi bila dobivena papirna pulpa. Daljnja faza izrade papira ovisila je o dvama specijaliziranim radnicima. Zadaća prvoga (eng. vatman) bila je uranjanje kalupa u vodenu suspenziju papirnih vlakana, čime je po vađenju kalupa na njemu formiran tanak sloj međusobno isprepletenih vlakana, koji bi potom proslijedio radniku koji je taj tanak sloj, nakon što je iz njega kapanjem uklonjen višak vode, prebacio na sloj

godine, u vrijeme kada je njihova radionica bila na svojem umjetničkom vrhuncu, a mladi Albrecht Dürer upravo je tamo dovršio naukovanje. To je jedna od najbolje dokumentiranih rano tiskanih knjiga i jedna od prvih koja je uspješno integrirala ilustracije i tekst. "The Nuremberg Chronicle," u World Digital Library, pristupljeno 30. listopada 2019., https://www.wdl.org/en/item/4108/.

37 Stromerov mlin prikazan je u koloriranom drvorezu u raskošnoj Nürnberškoj kronici 1493. uz podatak da je bila smještena izvan gradskih zidina zbog smrada i buke koju je proizvodila.

38 Hunter, Papermaking, str. 233.

39 Bloom, "Papermaking," str. 62.

40 Bull's Head And Mermaid, str. 16.

41 Bloom, "Papermaking," str. 61.

42 Bull's Head And Mermaid, str. 16.

43 Maceracija je izdvajanje vlakana lana iz stabljike močenjem u vodi i mehaničkom obradom. "Maceracija," u Hrvatska enciklopedija: 6: Kn-Mak, ur. August Kovačec (Zagreb: Leksikografski zavod Miroslav Krleža, 2004), str. 721.

44 Bull's Head And Mermaid, str. 12 i 16. 
filca ${ }^{45}$ preokrećući kalup naopako (eng. couchman). Na taj još nedovršen list papira postavio bi novi sloj filca spreman za sljedeći formirani list papira. Ne bi li proizvodnja bila ubrzana, radnici su istovremeno koristili dva kalupa kako bi se izbjegao prazan hod, tako da su se dvije opisane radnje zapravo odvijale istovremeno. $\mathrm{Na}$ taj način postignuta je proizvodnja od gotovo petsto listova papira dnevno. Kad bi se skupila određena količina tako napravljenih listova, uslijedilo je uklanjanje filca i prešanje, kojim bi bio uklonjen ostatak vode iz papira. Listovi su potom preneseni na završno sušenje na tavan mlina, gdje su vješani i tako sušeni na zraku. Završni korak u proizvodnji papira bilo je premazivanje listova keljivom i njihovo poliranje, čime je papir postao pogodan za pisanje. ${ }^{46}$

Promjene koje su Europljani unijeli u proizvodnju papira ticale su se i samoga kalupa. Bambusove trake i dlaka životinjskoga podrijetla, koje su se koristili u Kini u početcima proizvodnje, zamijenjeni su bakrenom i mjedenom žicom isprepletenom na jednak način tvoreći rešetku čiji se otisak može vidjeti na listovima ručno rađenih papira kada se izlože pozadinskom svjetlu. Takav kalup načinjen od žice korišten je na području današnje Španjolske već tijekom 12. stoljeća. Inovacija koju susrećemo u Europi uporaba je posebnoga "okvira" (eng. deckle) koji se je smještao na kalup i koji je radnicima služio za zadržavanje pulpe tijekom trešnje kojom se je vlakna nastojalo ravnomjerno rasporediti na kalupu. ${ }^{47}$

U odnosu na arapski svijet, jedna od glavnih prednosti koju su Europljani posjedovali u proizvodnji papira bile su europske rijeke i potoci na kojima su građeni mlinovi za proizvodnju papira. Iako kraće, europske rijeke teku brzo i snažno zbog neravnoga terena, proizvodeći veliku količinu energije za pokretanje mlinova, koja je još umnažana zahvaljujući domišljatosti proizvođača papira, koji bi nagibne čekiće u mlinovima rasporedili u serije i čijim su se kontinuiranim radom krpe pretvarale u papirnu pulpu visoke kvalitete. ${ }^{48}$ No upravo je nedostatak brzih rijeka u nekim dijelovima Europe doveo do sljedećega velikoga tehnološkoga napretka u proizvodnji papira. Tehnologija proizvodnje papira usavršavana je, pa su tako na području Nizozemske tijekom 17. stoljeća tamošnji proizvođači izumili novi način usitnjavanja krpa u papirnu pulpu. Godine 1680. zabilježena je po prvi puta uporaba takozvanoga hollandera ${ }^{49}$ koritastoga mlina sastavljenoga od korita sa središnjom pregradom, koja je omogućavala cirkulaciju suspenzije vlakana između oštrih i uskih noževa postavljenih na kućištu na dnu

\footnotetext{
45 Pust ili filc je netkana plošna tekstilija od vune ili finih dlaka zeca, angorskoga kunića ili deve, kojoj se cjelovitost postiže zamršivanjem vlakana (njem. Filz). "Pust," u Hrvatska enciklopedija: 9: Pri-Sk, ur. Slaven Ravlić (Zagreb: Leksikografski zavod Miroslav Krleža, 2007), str. 108.

46 Usp. Bull's Head And Mermaid, str. 13 i 14.

47 Usp. Hunter, Papermaking, str. 91; Hubbe i Bowden, "Handmade Paper," str. 1749.

48 Usp. Bloom, "Papermaking," str. 57; Dąbrowski, Paper Manufacture, str. 2.

49 Usp. Dąbrowski, Paper Manufacture, str. 483.
} 
korita (smještenih na jednoj strani korita) i valjku iznad njega. ${ }^{50}$ Zahvaljujući novomu načinu mljevenja vlakana, povećana je produktivnost mlinova za proizvodnju papira i do osam puta. Takvi strojevi, za čije je pokretanje bila dovoljna manja količina energije, bili su pogodni za mlinove pokretane snagom vjetra, kakvih je na području Nizozemske bio velik broj. Takvi su se mlinovi razvitkom nove tehnologije uključili u proizvodnju kvalitetnijih, bijelih papira, čija je proizvodnja do izuma hollandera bila rezervirana gotovo isključivo za vodene mlinove. ${ }^{51}$ Tehnološki napredak promijenio je i postupak proizvodnje, iz koje je tada polako izostavljen proces truljenja u usitnjavanju vlakana. Tomu je pridonijela i nestašica materijala za proizvodnju papira, pa se je u postupku proizvodnje u najvećoj mogućoj mjeri nastojalo svesti gubitke na minimum. ${ }^{52}$ Potražnja je za papirom, naime, uvelike porasla razvojem tiskarstva. Prve Gutenbergove Biblije tiskane su na pergameni, no pergamena je uskoro zamijenjena papirom, koji se je pokazao pogodnijom podlogom za tiskanje zbog svoje glatke površine te boljega i lakšega prianjanja tinte. ${ }^{53} \mathrm{~S}$ razvojem tiskarstva, potražnja za materijalom od kojega bi bio izrađivan papir rasla je tijekom godina. Do prve polovice 18. stoljeća, kada su se pojavile dostupnije knjige, ali i osnovane novine i časopisi, potražnja za krpama od kojih bi mogao biti proizveden papir toliko je porasla da su proizvođači papira čak i vodenim znakovima upozoravali potrošače: save rags! (“čuvajte krpe!"). Krpe su do kraja 18. stoljeća ostale glavni materijal za proizvodnju papira, no suočeni s njihovom nestašicom, od druge polovice 17. stoljeća znanstvenici su tragali za prikladnim alternativama, od kojih je drvo bilo to koje se je na kraju pokazalo kao najprikladnija zamjena. ${ }^{54}$ Prekretnica je u proizvodnji papira 1799. godina, kada je Francuz L. Robert konstruirao prvi stroj za izradbu papira. Taj je stroj mogao proizvesti papirnu traku dugu i do $15 \mathrm{~m}$. Pronalazak su usavršili Francuzi braća H. i S. Fourdrinier i Englez B. Donkin, pa je tako nastao stroj sposoban za formiranje papirnoga lista odvodnjavanjem, prešanjem, sušenjem i namatanjem papira u kontinuiranom postupku. Taj je stroj prema spomenutoj braći nazivan Fourdrinier, a na njemačkom govornom području udomaćen je naziv Langsiebmaschine, prema dugoljastomu obliku sita. Skoro istodobno (1805. godine) konstruirao je Englez J. Bramah sličan stroj s valjkastim sitom, a usavršili su ga F. Leistenschneider i A. Keferstein u razdoblju od 1814. do 1819.

\footnotetext{
50 "Proizvodnja papira," u Wikiwand, pristupljeno 26. siječnja 2021., https://www.wikiwand.com/hr/ Proizvodnja_papira; Bull's Head And Mermaid, str. 19.

51 Usp. Bull's Head And Mermaid, str. 20.

52 Usp. Hubbe i Bowden, "Handmade Paper," str. 1750 i 1757; Hunter, Papermaking, str. 162-163.

53 Usp. Hubbe i Bowden, "Handmade Paper," str. 1775-1776; Hunter, Papermaking, str. 62; Aleksandar Stipčević, Povijest knjige (Zagreb: Nakladni zavod Matice hrvatske, 1985), str. 259.

54 Usp. Stipčević, Povijest knjige, str. 309-313.
} 
godine. Tako je dvadesetak godina nakon Robertova pronalaska ručna izradba papira u malim kućnim radionicama prerasla u industrijsku proizvodnju. ${ }^{55}$

Važan tehnološki napredak u izradbi papira koji je prethodio strojnoj proizvodnji izum je tzv. tkanoga papira (eng. woven paper) polovicom 18. stoljeća, za čiju je proizvodnju karakteristična uporaba tanke mreže koja je bila postavljana na kalup i na kojoj je potom bila skupljana papirna pulpa. Rezultat takvoga načina izradbe bio je papir glatke površine, na kojem, zahvaljujući uporabi mrežice, nisu ostajali karakteristični otisci kalupa u obliku vodoravnih i paralelnih linija, nego otisak koji podsjeća na tkaninu. ${ }^{56}$
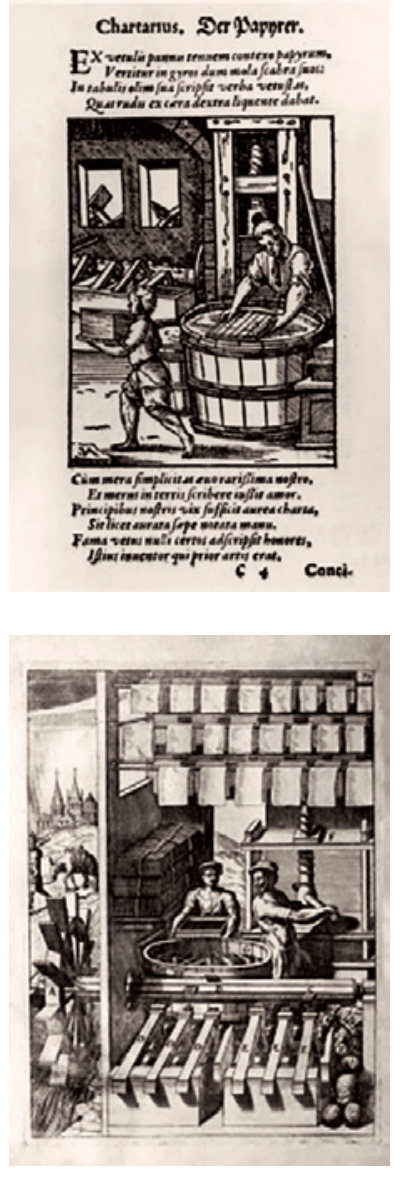

Slika 2. Jost Amman, Prikaz papirničara u Knjizi zanata autora Hartmana Schoppera; Jost Amman: Chartarius. Der Papyrer: Panopliji. Omnium illiberalium mechanicarum aut sedentarium artium genera kontinenti; Hartmannu Schopperu Francoforti ad Moenum, apud Georgium Coruinum, impensis Sigismundi Feyerabent, 1568.

Slika 3. Georg Andreas Böckler: Theatrum Machinarum Novum, Nüremberg, 1661.

\footnotetext{
55 J. Kos, "Papir," u Tehnička enciklopedija: 10: Oru-Polj (Zagreb: Jugoslavenski leksikografski zavod, 1986), str. 129.

56 Usp. Neil Harris, Paper and Watermarks as Bibliographical Evidence (Lyon: Institut d'histoire du livre, 2017), str. 24; Bull's Head And Mermaid, str. 20.
} 

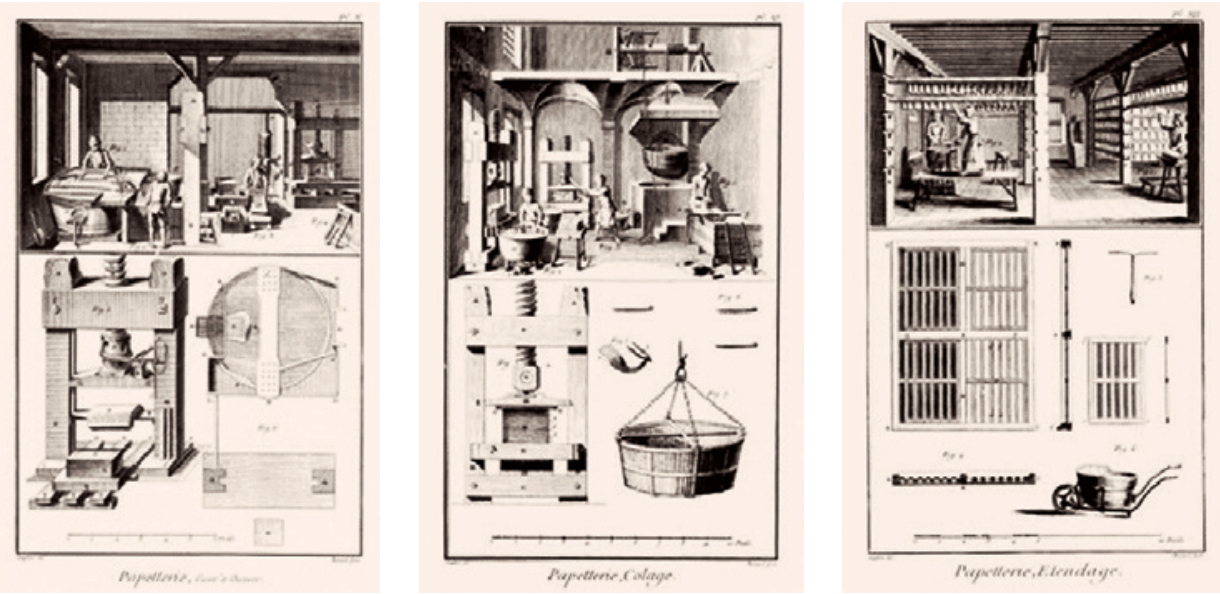

Slika 4. Faze proizvodnje papira: Plate X: Paper Manufacturing, Details of a Vat of a Mould Machine; Plate XI: Paper Manufacturing, Sizing; Plate XII: Paper Manufacturing, Drying (Encyclopédie, ou Dictionnaire raisonné des sciences, des arts et des métiers, vol. 5)

Postupak ručne proizvodnje papira zabilježen je na brojnim grafikama, od kojih je možda najpoznatija ona Josta Ammana, švicarsko-njemačkoga grafičara iz 16. stoljeća koji je kroz seriju grafika nastojao prikazati zanate svojega vremena, izradivši tako i grafiku posvećenu umijeću izradbe papira (Slika 2): papirničar koji sitom zahvaća papirnu pulpu iz bačve, a ispred njega je dječak koji u rukama nosi svežanj već formiranih listova papira. U pozadini prepoznajemo batove za usitnjavanje starih krpa i preša za papir, koji zorno dočaravaju postupak izradbe papira. Možemo spomenuti i grafiku Georga Andreasa Böcklera (Slika 3), hidrauličnoga inženjera iz Nürnberga iz 17. stoljeća, na kojoj je, uz papirničara koji sitom formira listove papira, prikazan i kotač vodenoga mlina, čija snaga pokreće batove za usitnjavanje krpa te postupak sušenja formiranih listova na užetu uz otvoren prozor. Detaljan prikaz proizvodnje papira u 18. stoljeću donosi nam dodatak Diderotove Encyclopédie, ${ }^{57}$ gdje je kroz 13 grafika prikazan cjeloviti postupak izradbe papira: sortiranje krpa, fermentacija (kuhanje krpa u lužini), rezanje krpa na manje komade, pogon s batovima za usitnjavanje vlakana (uz detaljne prikaze mehanizma batova), izradba odnosno tkanje papirnih sita, formiranje lista i njegovo prešanje te na kraju dorada listova želatinom u sloju ili uranjanjem u kupku (Slika 4). ${ }^{58}$

\footnotetext{
57 "Papetterie," u Recueil de planches, sur les sciences, les arts liberaux, et les arts mechaniques, avec leur explication: Quatrieme livraison, 248 Planches (Paris: Briasson, 1767), str. [581-611].

58 Timothy Barrett, "Paper Through Time: Nondestructive Analysis of 14th- Through 19th-Century Papers," The University of Iowa, 11. lipnja 2020., pristupljeno 1. rujna 2021., http://paper.lib.uiowa. edu/index.php.
} 


\section{Dodatci u papiru kroz povijest}

Od samoga početka proizvodnje papira, da bi se papirom moglo rukovati i na njemu pisati, crtati i slikati, dodavana su mu ljepila, punila, boje i, po potrebi, drugi dodatci. Kao najčešći dodatak za poboljšanje kvalitete papira korišteno je keljivo. Dodavano je i nanošeno na nekoliko načina. U početku je premazivano na već formiran vlažan list papira ili uranjanjem u njega, no kasnije je keljivo dodavano u papirnu masu. Sve je imalo za cilj međusobno bolje povezivanje vlakana, ili svega zajedno s drugim sastojcima dodanim papiru. Keljivo poboljšava mehanička i površinska svojstva papira, regulira sposobnost papira da upija tuševe i tinte, što poboljšava kvalitetu pisanja. Najčešće su korištena keljiva u starim papirima kroz povijest škrob, tutkalo i želatina, a kasnije su korištene i biljne gume, bjelanjak, žutanjak, alaun i kazein, kolofonij i drugi. ${ }^{59}$

Već u 8. stoljeću Kinezi su za premazivanje primjenjivali gips i keljivo pripravljeno od lišajeva, a kasnije keljivo pšeničnoga škroba. Arapi su kasnije unaprijedili postupak proizvodnje papira te su za premazivanje koristili škrob, koji su polirali kako bi dobili površinu visokoga sjaja nalik pergameni. ${ }^{60}$

Najstariji papiri proizvedeni u Europi pronađeni u ranim španjolskim rukopisima slični su tradicionalnomu arapskomu papiru. Pripravljena gusta ljepljiva tvar nanošena je na listove papira nekoliko puta kako bi bile ispunjene rupe i izravnate površinske neravnine, a potom je papir sušen na zraku. U tom postupku premaz je pripravljan od riže ili gume tragant, ${ }^{61}$ nakon čega je papir uranjan u premaz, a potom sušen na zraku vješanjem na uže ili polaganjem na čistu krpu. Ta metoda premazivanja arapska je praksa proizvodnje papira, koja je nastavljena na području (današnje) Španjolske i u 14. stoljeću.

$\mathrm{Za}$ osnivanje prve tvornice papira u gradu Fabrianu zasluga se pripisuje Pietru Milianu, koji je okupio nekoliko malih poduzeća za osnivanje radionice papira Cartiere Miliani-Fabriano sredinom 18. stoljeća. Od samoga začetka rada radionice papira u Fabrianu, želatina je korištena za premazivanje papira. Pretpostavlja se da je sirovina za želatinu dobivena od proizvođača koža u Fabrianu, koji je radio blizu tvornice papira. Papir je uranjan u kadu vrućega premaza. Nakon toga je prešan pod laganim teretom kako bi premaz bio ravnomjerno raspoređen po čitavoj površini papira, a višak keljiva bio uklonjen.

\footnotetext{
59 Suzana Njegač i Andreja Dragojević, "Premazi pisanog, crtanog/slikanog i tiskanog gradiva na papiru i pergameni," u 21. seminar Arhivi, Knjižnice, Muzeji: Mogućnosti suradnje okruženju globalne informacijske strukture, ur. Mirna Willer i Ivana Prgin (Zagreb: Hrvatsko arhivističko društvo, 2018), str. 365.

60 Hend Mahgoub i dr., "Material Properties of Islamic Paper," Heritage Science 4, br. članka 34 (studeni 2016), pristupljeno 21. lipnja 2021., https://heritagesciencejournal.springeropen.com/articles/ 10.1186/s40494-016-0103-4.

${ }^{61}$ Tragant ili tragakant (lat. gummi tragacantha) osušeni je i žilavi sok leptirnjače Astragalus gummifer što uspijeva u jugozapadnoj Europi, Siriji i Iranu.
} 
Porastom proizvodnje papira na Apeninskom poluotoku u 14. stoljeću, uporaba želatine nalazi široku primjenu kod izradbe papira za pisanje. Kod proizvodnje toga papira želatina je korištena za sprječavanje razlijevanja tinte i radi lakšega pisanja (pero je lakše "klizilo" po papiru). Papir koji je korišten za tiskanje inkunabula (knjiga tiskanih do 1500. godine) ondje je također premazivan želatinom, zahvaljujući čemu se i danas odlikuje svojim "besprijekornim" izgledom. No u državama njemačkoga govornoga područja želatina iz ekonomskih razloga nije korištena u proizvodnji papira za tiskanje. Naime, vodoodbojnim tintama napravljenima na uljnoj osnovi koje su pritom korištene ona nije bila potrebna, pa se je tako izbjegavao dodatni trošak..$^{62}$

U 16. stoljeću uz želatinu korišten je i alaun (kalijev aluminijev sulfat $\mathrm{KAl}(\mathrm{SO}) 2$ x $12 \mathrm{H} 2 \mathrm{O}$ ), koji je od sredine 17. stoljeća ušao u širu primjenu u proizvodnji papira. Njegova je glavna uloga bila vezanje želatine, kojom je premazivan papir, s površinom od celuloznih vlakana, radi sprječavanja razlijevanja crnila. $\mathrm{U}$ početku je nakon nanošenja želatine na papir nanošena otopina alauna. Oba postupka provođena su uranjanjem oblikovanoga lista papira prvo u otopinu želatine a kasnije u otopinu alauna s međufazama sušenja listova. Kasnije je, zbog ekonomičnosti postupka, u otopinu želatine dodavan alaun. S obzirom na sastav alauna, kalijev aluminijev sulfat, $\mathrm{pH}$ papira postaje kiseo, što je bilo vidljivo i prema količini alauna koja je $s$ vremenom rasla od 16. do 20. stoljeća, čime se je i pH papira mijenjao od 6,7 do $4,8 .^{63}$

Imberdis ${ }^{64}$ u kasnom 17. stoljeću navodi dva testa za kontrolu kvalitete premaza na papiru. Prvi test korišten je za ispitivanje zvonkosti, a drugi za upojnost papira. Danas je moguće sastav papira analizirati suvremenim spektralnim analizama ${ }^{65}$ kao što su FTIR ${ }^{66}$ i Ramanova spektroskopija. ${ }^{67}$ Oni kao rezultate

\footnotetext{
62 Jedert Vodopivec Tomažič, "Valvasor's Glory of the Dutchy of Carniola, 1689, Vol. III: Comparative Analysis of Binding Structure and Paper," u Bookbindings: Theoretical Approaches and Practical Solutions, ur. Nataša Golob i Jedert Vodopivec Tomažič (Turnhout: Brepols, 2017), str. 246.

63 Irene Brückle, "The Role of Alum in Historical Papermaking," The Abbey Newsletter 17, br. 4 (1993): str. 53-57; William J. Barrow, Permanence/Durability of the Book-VII. Physical and Chemical Properties of Book Papers, 1507-1949 (Richmond, Virginia: Barrow Research Laboratory, 1974), str. 16.

${ }^{64}$ Isusovac Jean Imberdis objavio je 1693. prvu knjigu o proizvodnji papira Papyrus sive ars confiendae papyri iz Cleremonta, a tiskao ju je Damian Boujon.

${ }_{65}$ Timothy Barrett, Mark Ormsby i Joseph B. Lang, "Non-Destructive Analysis of 14th-19th Century European Handmade Papers." Restaurator 37, br. 2 (2016): str. 107; Michele R. Derrick, Dusan C. Stulik i James M. Landry, Infrared Spectroscopy in Conservation Science (Los Angeles: Getty Conservation Institute, 1999).

${ }_{66}$ FTIR (Fourier Transform Infrared Spectroscopy Technique) je spektroskopija kojom se identificiraju sastavnice uzorka analizom apsorpcijskih ili emisijskih spektara infracrvenoga zračenja. Vladan Desnica, "Instrumentalna analiza, uz istoimeni nastavni kolegij na Odsjeku za restauriranje i konzerviranje, umjetnina," (Skripta, Akademija likovnih umjetnosti Sveučilišta u Zagrebu, 2012), str. 47.

${ }^{67}$ Ramanova spektroskopija temelji se na otkriću iz 1928., kada je indijski fizičar C. V. Raman uočio da se mala količina raspršenoga vidljivoga svjetla s određenih molekula razlikuje od početnoga, upad-
} 
daju spektre koje uspoređujemo sa spektrima poznatoga uzorka te je usporednom metodom moguće utvrditi podrijetlo dodataka u papiru. $\mathrm{XRF}^{68}$ i $\mathrm{PIXE}^{69}$ analizama možemo dobiti elementni sastav papira.

\section{Svojstva ručno rađenih papira}

Svi su papiri do izuma stroja za izradu papira na kraju 18. stoljeća jedinstveni: njihova unikatnost postignuta je upravo pojedinačnom proizvodnjom svakoga lista. Time je papirničar ostavio svoj trag na svakom od njih, iako se tehnologija izrade i vještina papirničara s vremenom usavršavala.

Tako je jedno od svojstava ručno rađenih papira nejednakost u debljini, ${ }^{70}$ nastala u postupku proizvodnje, gdje se tijekom tréšnje kalupa, iako relativno ravnomjerno, papirna vlakna ipak nepravilno rasporede po dužini kalupa formirajući list papira. Takvom se izradbom nastali listovi papira međusobno razlikuju i formatima koji nisu jednaki, ni strogo pravokutni. ${ }^{71}$ Ručno rađeni papir lako prepoznajemo i po takozvanom živom rubu (Slika 5) (eng. deckle edge) nastalom nejednakim raspoređivanjem papirnih vlakana na rubovima lista. $U$ početnim godinama razvoja tiskarstva takav je rub rijetko obrezivan, no $s$ obzirom na to da su postojali i oni koji su to vidjeli kao nesavršenost, postojali su i takvi slučajevi. ${ }^{72} S$ razvojem strojno rađenih papira to je svojstvo ručno rađenih papira postalo cijenjeno, jasno ih na taj način razlikujući od strojno rađenih. ${ }^{73}$ Uz format i debljinu, ručno rađene papire odlikuje i neujednačenost u boji, koja je potjecala od materijala od kojih je papir proizveden: najkvalitetniji papir odlikovala je krem boja, a one manje kvalitete obično su odlikovali tamniji sivkasti ili smeđi tonovi. ${ }^{74}$

Pregledom listova uz pozadinsko osvjetljenje postaju vidljiva i ostala svojstva ručno rađenih papira. Tijekom proizvodnje nerijetko bi se dogodilo da bi s ruku radnika kapljica vode pala na kalup na kojem se je oblikovao list papira. Takva kapljica uzrokovala bi preraspodjelu vlakana, prorijedivši ih, uzrokujući

\footnotetext{
noga svjetla. Također, te razlike u frekvenciji ovise o kemijskoj strukturi molekula odgovornih za raspršenje. Desnica, "Instrumentalna analiza," str. 53.

68 XRF (eng. X-ray fluorescence analysis, rendgenska fluorescentna analiza) jedna je od najprimjerenijih metoda za kvalitativno i kvantitativno istraživanje anorganskih materijala. Desnica, "Instrumentalna analiza, "str. 36.

69 PIXE (eng. proton induced X-ray emission, protonima inducirana emisija rendgenskoga zračenja), usp. Desnica, "Instrumentalna analiza," str. 42.

70 Usp. Desnica, “Instrumentalna analiza, ” str. 456.

71 Usp. Desnica, "Instrumentalna analiza, " str. 546.

72 Usp. Desnica, "Instrumentalna analiza, ” str. 224; Hubbe i Bowden, "Handmade Paper," str. 1765.

73 Usp. Hunter, Papermaking, str. 456.

74 Usp. Hunter, Papermaking, str. 224.
} 


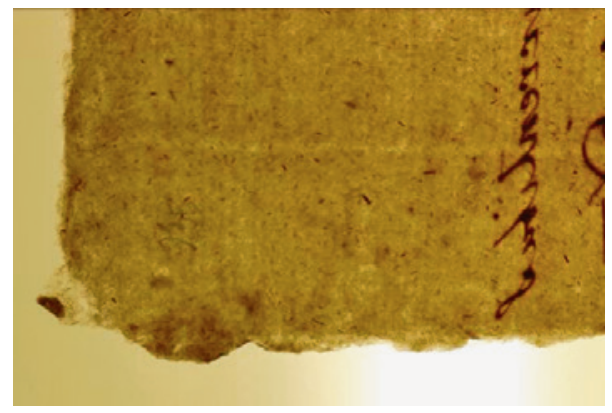

Slika 5. HR-HDA-31. Srijemska županija, Acta S.I. Civilis, svežanj 923 (1795.1796.): pregled listova 235 i 231 pomoću pozadinskog osvjetljenja: živi rub (deckle edge)

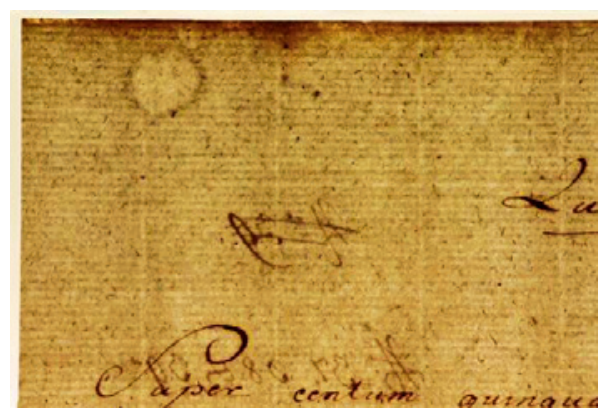

Slika 6. HR-HDA-31. Srijemska županija, Acta S.I. Civilis, svežanj 923 (1795.1796.): kapljica (papermaker's tear), vodoravne i okomite linije (chain i laid lines)

manju debljinu papira na tom mjestu. Tako se na listu papira osvijetljenom pozadinskim svijetlom nerijetko mogu zapaziti kružići $i^{75}$ u engleskom jeziku poznati pod nazivom papermakers tears ${ }^{76}$ ("suze proizvođača papira") (usp. Slika Ø).

Tijekom postupka sušenja i prešanja papira, vlakna filca nerijetko bi ostavila otisak na površini papira, utkavši se tako u samu teksturu papira. Uz vlakna filca, ne čudi vidjeti ni dlake ljudskoga podrijetla među papirnim vlaknima. One su tamo dospjele od samih majstora koji su taj papir izrađivali. ${ }^{77} \mathrm{Na}$ ručno rađenim papirima moguće je primijetiti i tamnije točkice, koje su nastale na mjestima gdje je došlo do zapetljavanja vlakana. ${ }^{78}$

Još jedno svojstvo koje nam otkriva pozadinsko svjetlo tipično je za papire nastale tijekom 15. i 16. stoljeća: po njihovoj sredini moguće je uočiti karakterističnu mrlju nastalu na mjestu gdje su listovi bili obješeni za vrijeme sušenja. ${ }^{79}$

Uz ta svojstva na koja s vremena na vrijeme naiđemo pri pregledu ručno izrađenih papira, valja spomenuti i ona koja posjeduju svi tradicionalno ručno rađeni papiri: otisak kalupa na kojem je papir izrađen u obliku rešetke na kojoj se jasno razlikuju istaknutije okomite linije (eng. chain lines) te one manje istaknute, vodoravne linije (engl. laid lines), uzrokovan načinom na koji je papirna pulpa bila raspoređena po kalupu. Naime, tijekom vađenja kalupa iz vodene sus-

\footnotetext{
Usp. Hunter, Papermaking, str. 225.

76 Usp. Bloom, "Papermaking," str. 61.

77 Usp. Hunter, Papermaking, str. 226.

78 Usp. Hunter, Papermaking, str. 226.

79 Usp. Hunter, Papermaking, str. 188.
} 
penzije, tijekom otjecanja viška vode, više vlakana raspoređuje se u prostoru između žica od kojih je kalup napravljen. Kako se manje vlakana raspoređuje po površini žica, tu je papir tanji ${ }^{80}$ i ta se razlika u debljini jasno vidi izloži li se list papira pozadinskomu svjetlu. Pozadinsko osvjetljenje otkriva i moguće nepravilnosti u linijama, koje upućuju na to da je kalup u trenutku sušenja lista pomoću filca majstoru skliznuo iz ruku, poremetivši tako raspored vlakana. ${ }^{81}$ Papire izrađene do 1800. godine možemo prepoznati i po karakterističnim tamnijim mrljama koje teku duž okomitih linija, uzrokovanih gušćim nanosom pulpe u tom dijelu kalupa, poznatih pod nazivom antique laid. ${ }^{82}$ su znakovi.

Ipak, možda najzanimljivije vidljivo svojstvo ručno rađenih papira vodeni

\section{Vodeni znakovi ručno rađenih papira}

Vodeni znakovi jedna su od značajki ručno rađenih papira (Slika 7, Slika 8 i Slika 9). Isprva nevidljivi, ukazuju se promatračevu oku izloži li se list papira izvoru pozadinskoga svjetla. Kao i chain, laid linije nastaju otiskom kalupa za izradu papira zahvaljujući specifičnomu načinu na koji se papirna vlakna raspoređuju po kalupu tijekom proizvodnje papira, stvarajući tanji sloj na mjestu na kojem se nalazi žica.

Vodeni znakovi u papiru srednjega vijeka mogu se smatrati simbolom, fragmentom toga svijeta, kako je to tada bilo shvaćeno. Za početak, oni su europski izum: nema ih u starim kineskim ili arapskim papirima. To se može objasniti činjenicom da su proizvođači papira u Europi počeli koristiti krute kalupe za papir na koje su mogle biti pričvršćene žičane figure. U povijesti izradbe papira u srednjem vijeku u Europi vodeni znakovi pojavili su se prilično kasno.

$S$ kalupima izrađenima od drvenoga okvira i žičane rešetke, ideja o formiranju oblika od žice koji bi se mogao pričvrstiti na kalup te, poput rešetke na koju je pričvršćen, ostaviti svoj otisak na listu papira razvila se je tijekom 13. stoljeća. ${ }^{83}$ Ideja se je po prvi put javila na današnjem području sjeverne Italije, odakle su i sačuvani najstariji papiri s vodenim znakovima: najstariji, $s$ vodenim znakom u obliku slova F, potječe iz Cremone i datira iz 1271. godine. ${ }^{84}$

Najraniji vodeni znakovi bili su jednostavnih oblika: u obliku kruga, trokuta, ovala, križeva - ukratko oblika koji su se relativno jednostavno mogli obli-

80 Usp. Bull's Head And Mermaid, str. 14.

81 Usp. Hunter, Papermaking, str. 226.

82 Usp. Hunter, Papermaking, str. 120-121.

83 Usp. Bull's Head And Mermaid, str. 29.

84 Usp. Bull's Head And Mermaid, str. 30. 

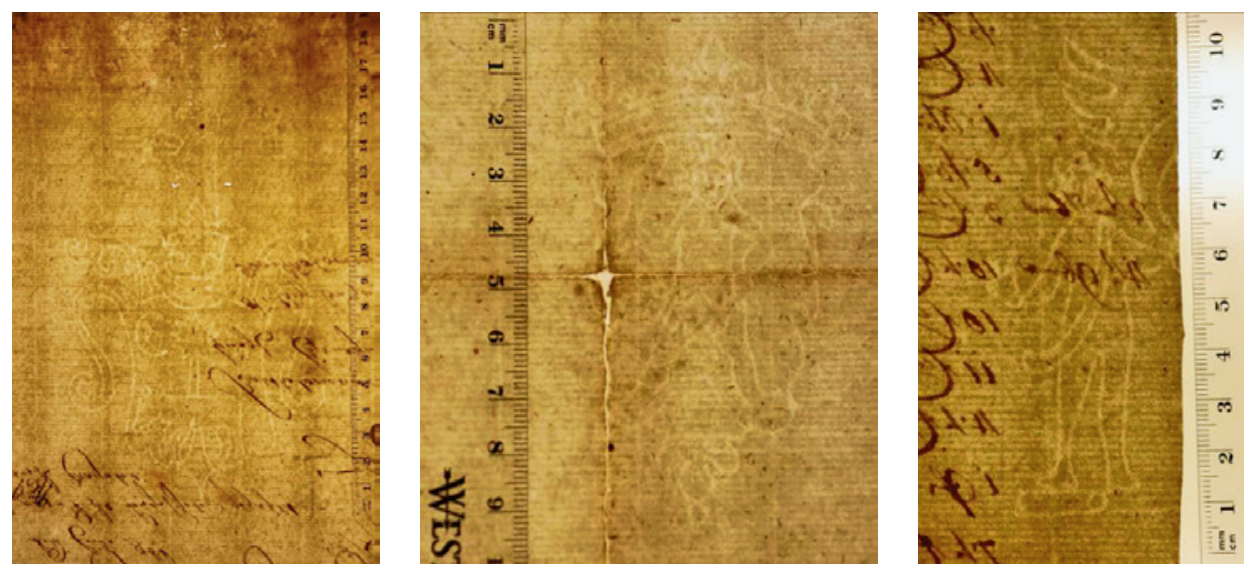

Slike 7-9. HR-HDA-31. Srijemska županija, Acta S.I. Civilis, svežanj 923 (1795.1796.): primjeri vodenih znakova pronadenih na listovima 198, 186 i 161

kovati od žice, ${ }^{85}$ premda se prije 1300 . godine mogu naći i vodeni znakovi koji nose imena vlasnika mlinova. ${ }^{86}$ Ispočetka su ih izrađivali sami majstori koji su izrađivali papir, no kasnije tu ulogu preuzimaju zlatari i srebrnari ${ }^{87} \mathrm{Od}$ jednostavnijih oblika karakterističnih za razdoblje koje je trajalo do prve četvrtine 15. stoljeća postupno su se razvili kompleksniji oblici, čemu je zasigurno pridonijela i mogućnost izrade tanje žice kojom je izrada složenijih oblika bila uvelike olakšana. ${ }^{88}$ Motive koje pronalazimo u vodenim znacima možemo podijeliti u četiri glavne skupine: najjednostavniji oblici (krug, trokut, križ i sl.), motivi vezani za ljude i ljudske aktivnosti, biljni te životinjski oblici (među kojima možemo posebno istaknuti one vezane za mitološka i fantastična bića) ${ }^{89}$

O tom koja je zapravo bila svrha vodenih znakova postoje različite teorije, ${ }^{90}$ no najvjerojatnije je bila riječ o oznakama podrijetla papira, a time i njegove kvalitete. Potvrdu toga donosi traktat iz prve polovice 14. stoljeća Tractatus de insignis et armis Bartola de Sessaferrata, u kojem autor govori o oznakama majstora umetnutima u papir, a koje su služile njihovoj identifikaciji, kao i ozna-

\footnotetext{
85 Usp. Hunter, Papermaking, str. 268.

86 Usp. Bull's Head And Mermaid, str. 30.

87 Usp. Bull's Head And Mermaid, str. 15.

88 Usp. Bloom, "Papermaking," str. 61.

89 Usp. Hunter, Papermaking, str. 268-270.

90 Po jednoj teoriji služili su kao oznake kalupa i keljiva korištenih za određenu vrstu papira namijenjene nepismenim majstorima. Po drugoj teoriji to su simboli i poruke umetnute u papir u svrhu vjerske propagande. Tu je i ona najjednostavnija teorija po kojoj se je to jednostavno umjetnički izričaj majstora. Hunter, Papermaking, str. 258-259.
} 
čavanju njihove provenijencije. ${ }^{91}$ Uzmemo li u obzir kako je primjerice papir proizveden u Fabrianu bio cijenjen zbog svoje kakvoće, oznaka njegova podrijetla bila je ujedno i potvrda njegove kvalitete. Ujedno je tako vodeni znak služio i kao mjera za suzbijanje krivotvorina, jer kroz povijest su ostali zabilježeni slučajevi u kojima bi papir manje kvalitete bio obilježen vodenim znakom korištenim za označavanje kvalitetnijih listova papira. ${ }^{92}$

Vodeni su znakovi tako nerijetko nosili imena poznatih papirnih mlinova, ili njihove inicijale, ili su pak svojim motivima upućivali na određene karakteristike ili događaje iz povijesti samih majstora. ${ }^{93}$ Među kompleksnijim motivima zasigurno se ističu grbovi teritorija države, grada ili posjeda na kojem je izrađen papir.

Danas su vodeni znakovi pomoćno sredstvo u datiranju djela nastalih na papirnom nositelju. Preduvjet je za to postojanje već datiranoga lista papira $s$ istovjetnim vodenim znakom. ${ }^{94}$ Pri tom valja biti svjestan kako je tijekom izrade papira korišten par kalupa radi brže izrade, iz čega proizlazi postojanje dva slična, ali ne i potpuno identična vodena znaka, ma koliko te razlike bile suptilne. Takav par zovemo blizancima (eng. twin watermarks). ${ }^{95}$

Uz glavni znak nerijetko nalazimo i manji znak, tzv. kontramarku (eng. countermark) (Slika 10, Slika 11 i Slika 12). Po prvi put se pojavljuju u papirima venecijanske proizvodnje, tijekom druge polovice 15 . stoljeća. ${ }^{96}$ Nerijetko su bile jednostavnih oblika (križ, list i sl.), a često su inicijali proizvođača papira, po kojima je moguće odrediti provenijenciju papira. Otuda vjerojatno i njihov smještaj u kutovima listova papira, olakšavajući tako trgovcu provjeru znaka bez potrebe vađenja cijeloga papira iz snopa. Kako su u početku bile smještene u kutove, otuda im na engleskom govornom području naziv cornermark. U knjigama su često upravo stoga vidljivije od glavnih vodenih znakova, koji najčešće postaju teško vidljivi jer ih prekriva tekst ili stoga što ti dijelovi, za razliku od kutova, nerijetko završe u hrptenom dijelu knjiga. Tijekom vremena i te su se manje oznake razvijale u veće i istaknutije znakove: tijekom 16. stoljeća u talijanskim papirima kontramarka je premještena na poziciju zrcalnu vodenomu znaku i njezine dimenzije rastu. Poznati su slučajevi kada su takve kontramarke dobivale i svoje vlastite dodatne vodene znakove smještene u kut papira. ${ }^{97}$

\footnotetext{
91 Usp. Bull's Head And Mermaid, str. 11.

92 Usp. Bull's Head And Mermaid, str. 16 i 30.

93 Usp. Bull's Head And Mermaid, str. 30-31.

94 Usp. Bull's Head And Mermaid, str. 34.

95 Usp. Harris, Paper and Watermarks, str. 50.

96 Usp. Bull's Head And Mermaid, str. 41.

97 Usp. Harris, Paper and Watermarks, str. 53-54.
} 

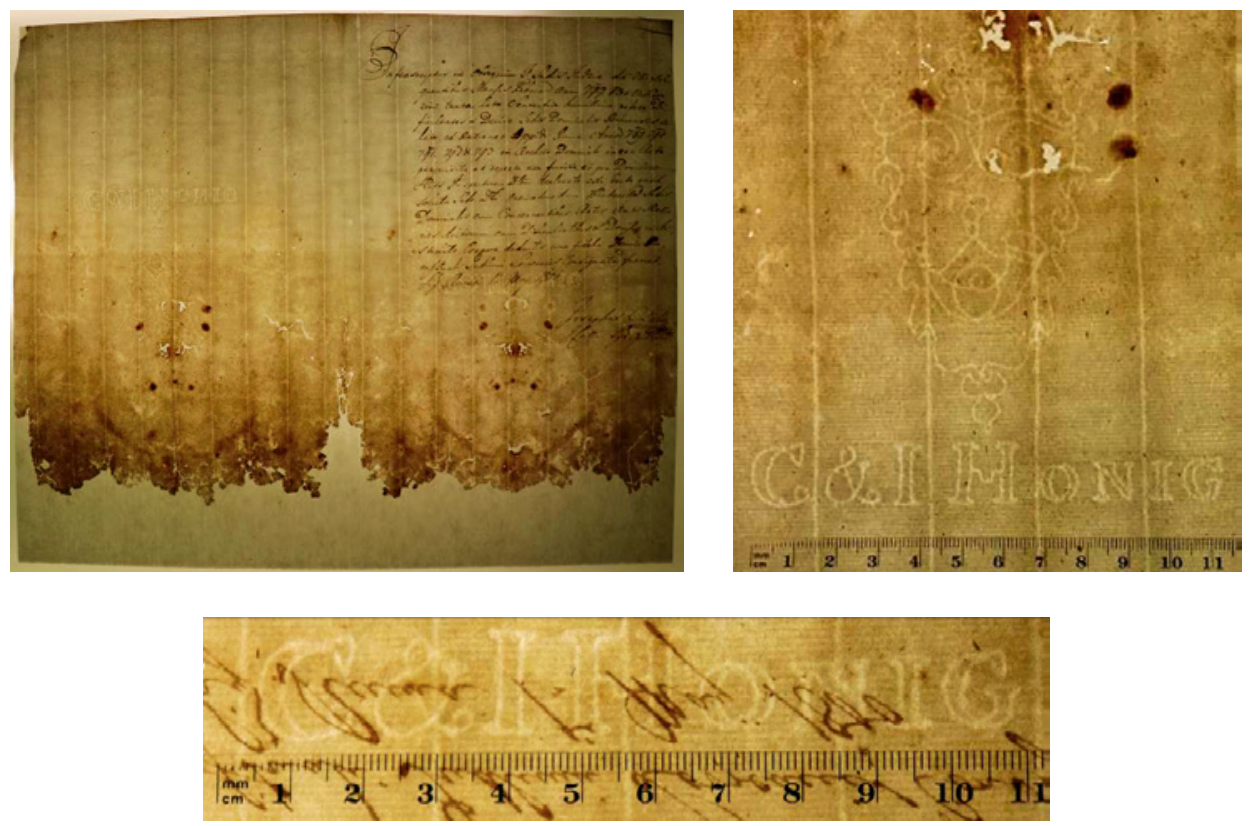

Slike 10-12. HR-HDA-31. Srijemska županija, Acta S.I. Civilis, svežanj 923 (1795.1796.), arak 96/97: vodeni znak u obliku grba s natpisom obitelji Honig s pripadajućom kontramarkom istog natpisa

Nije neobično u knjigama naići na brojne različite vodene znakove: rezultat je to velike potražnje za papirima, gdje su se tiskare opskrbljivale papirima proizvedenim u različitim mlinovima kako bi namirile svoje potrebe. Uz to, valja uzeti u obzir mogućnost da su se papiri različitih provenijencija uzimali namjerno, ne bi li se smanjila potrošnja visoko kvalitetnoga papira miješajući ga $s$ onim manje kvalitetnim. ${ }^{98}$

S obzirom na njihovo mnoštvo, različitost i mogućnosti korištenja u istraživanju djela nastalih na papirnom nositelju, ne čudi kako su s vremenom vodeni znakovi postali predmet skupljanja i izučavanja.

Prve veće zbirke vodenih znakova objavio je N. Likhachev, ${ }^{99}$ koji je prikupljao podatke o proizvodnji papira u Rusiji te se je bavio pitanjima provenijen-

\footnotetext{
98 Usp. Bull's Head And Mermaid, str. 41.

99 Nikolaj Petrovič Likačev (1862.-1936.), ruski povjesničar koji se je bavio analizom papira i vodenih znakova na ruskim i europskim rukopisima. Vladimir Mošin, "Filigranologija kao pomoćna historijska nauka," Zbornik Odsjeka za povijesne znanosti Zavoda za povijesne i drustvene znanosti Hrvatske akademije znanosti i umjetnosti 1 (1954): str. 25-93.
} 
cije znakova, prikupivši za svoju prvu knjigu 783 vodena znaka, a za drugu pod naslovom Paleografska važnost vodenih znakova u 3 sveska 1899. godine 4.268 znakova. ${ }^{100}$ Još veću važnost proučavanju vodenih znakova daje Charles M. Briquet objavom knjige sa 16.112 prikaza vodenih znakova iz 1923 . godine, čime su postavljeni temelji za filigranologiju kao jednu od pomoćnih povijesnih znanosti ${ }^{101}$ čiji su predmet izučavanja vodeni znakovi.

Kroz povijest bilo je istraživača koji su pridonijeli razvoju filigranologije. Vladimir Mošin izdvaja ih nekoliko te navodi da među prve zbirke vodenih znakova pripada zbirka u Britanskom muzeju, $s 1.000$ listova, koja se ondje nalazi od 1699. godine, a sastavio ju je Humphry Wanley. ${ }^{102}$ Kasnije su kroz djela istraživača u Engleskoj, Njemačkoj i Rusiji objavljeni prikupljeni vodeni znakovi, što pokazuje važnost njihova doprinosa u razvoju povijesnih znanosti. Najveći doprinos u istraživanjima na tom području dao je Charles-Moïse Briquet, ${ }^{103}$ koji je objavio nekoliko rasprava. U njima je dao odgovore na niz dotada nerazjašnjenih pitanja iz povijesti papira: o početcima proizvodnje, o sastavu arapskoga papira, o tom je li se stari istočni papir proizvodio drugačijom tehnologijom nego zapadni papir, o zapadnoj tehnologiji koja je uvela vodene znakove u svoju proizvodnju u 13. stoljeću na području današnje Italije. U Ženevi 1907. godine Briquet je objavio svoje djelo Les Filigranes: Dictionnaire historique des marques du papier des leur apparition vers 1282 jusqu*en 1600 avec 39 figures dans le texte et 16112 fac-similes de filigranes, $I-I V$, veliki priručnik vodenih znakova (s vodenim znakovima pronađenima na dokumentima u razdoblju od 1282. do 1600.), koji predstavlja rezultat njegova životnoga rada. ${ }^{104}$

Henri Alibaux (1872.-1941.) prodavač i pisac knjiga na temu papira, u tekstu Methode de travail de C. M. Briquet prikazao je način prikupljanja i sistematizacije gradiva za priručnik toga osnivača filigranologije. ${ }^{105}$ Briquet je precrtavao znakove na proziran papir $9,5 \mathrm{~cm}$ x $12 \mathrm{~cm}$ i stavljao u kuverte s naznakom arhiva u kojem je pronašao pojedini znak. Nakon što je eliminirao ranije pri-

\footnotetext{
${ }^{100}$ Mošin, "Filigranologija kao pomoćna historijska nauka," str. 31.

${ }^{101}$ Mošin, "Filigranologija kao pomoćna historijska nauka," str. 31.

102 Mošin, "Filigranologija kao pomoćna historijska nauka," str. 27.

103 Charles-Moïse Briquet (1839.-1918.) bio je švicarski trgovac papira i istraživač papira. Postao je poznat po svojim istraživanjima o povijesti papira i vodenih znakova srednjega vijeka i rane renesanse. Godine 1908. Sveučilište u Ženevi dodjeljuje mu počasni doktorat. Briquet se smatra jednim od najvažnijih istraživača papira.

${ }_{104}$ Tijekom 15 godina radio je u 235 biblioteka i u svim većim arhivima, pregledavši do 30.000 notarskih i drugih službenih knjiga i oko 1.500 mapa, odakle je izvadio oko 44.000 crteža znakova i oko 65.000 bilježaka. Mošin, "Filigranologija kao pomoćna historijska nauka," str. 31.

${ }^{105}$ Henri Alibaux, "Methode de travail de C. M. Briquet (avec Bibliographie d' ouvrages publies en France et en Belgique sur l'histoire du Papier et les Filigranes depuis 1907)," Monumenta chartae papyraceae historiam illustrantia: Collection of Works and Documents Illustrating the History of Paper, ur. F. Labarre (Hilversum, Holland: Paper Publications Society, 1952).
} 
mjerke, prenosio je podatke o njima na karticu najstarijega primjerka. Klasificirao je kartice po predmetima, svrstavao po kronologiji i signirao. Podatci koje je pisao na kartici obuhvaćali su: 1. naziv filigrana, 2. provenijenciju dotičnoga znaka (arhiva), 3. oznaku dokumenta, 4. mjesto gdje je dokument bio napisan, 5. datum kada je bio napisan, 6 . format, 7 . opis potke, 8 . signaturu u seriji dotičnoga predmeta.

Godine 1950. Emile Joseph Labarre ${ }^{106}$ pokrenuo je udruženje Paper Publication Society, u sklopu kojega je objavljeno niz izdanja Monumenta chartae papyraceae historiam illustrantia. Od tada je objavljeno niz bitnih djela velikih europskih povjesničara papira $\mathrm{i}$ istraživača vodenih znakova. Serija je započela radom Edwarda Heawooda, a uslijedile su publikacije Aurelija i Augusta Zonghija, Alfreda Henryja Shortera, Waltera F. Tschudina, Georga Einedera, Zoje Vasiljevske Učastkine i Johanna Lindta. ${ }^{107}$ Serija je nastavljena i nakon Labarreove smrti, samo je sponzorstvo proslijeđeno Zakladi Labarre.

Jedna od važnijih osoba u području filigranologije svakako je Gerhard Piccard (1909.-1989.), njemački slikar, arhivist i povjesničar, poznat po svojem radu na istraživanju vodenih znakova. Stvorio je najveću zbirku vodenih znakova na svijetu. Njegov rad u Glavnom državnom arhivu (Hauptstaatsarchiv) u Stuttgartu sadrži oko 92.000 dokumenata iz srednje i zapadne Europe. U svojem tiskanom izdanju Findbüchern Piccard je objavio 17 svezaka s 4.540 tipova vodenih znakova i 44.497 pojedinačnih crteža znakova. Donedavno je više od polovice njegove zbirke bilo dostupno samo kao dio spisa u Glavnom državnom arhivu u Stuttgartu (inventar J 340). U međuvremenu, kompletna zbirka Piccard dostupna je kao digitalna prezentacija na Internetu. ${ }^{108}$

Međunarodno udruženje povjesničara papira (IPH - International Paper Historians) razvilo je standarde za registriranje papira s i bez vodenih znakova. Standard za registraciju tehnički je standard koji definira kriterije, vrste papira i vodenih znakova, utvrđujući njihov naziv i specifikaciju na šest jezika, kako bi se osigurala međunarodna kompatibilnost podataka na papiru. ${ }^{109}$

U današnje vrijeme postoji nekoliko mrežnih baza podataka vodenih znakova, koje su nastale kao rezultat istraživanja pojedinaca unutar arhivskih ili knjižničnih ustanova u Europi. Ideja da se stvori jedna velika baza podataka koja će povezivati europske baze, a biti dostupna što širemu krugu istraživača potekla

\footnotetext{
${ }^{106}$ Emile Joseph Labarre (1883.-1965.) bio je europski jezikoslovac, povjesničar i istraživač vodenih znakova.

${ }^{107}$ B. J. Ginneken-van de Kasteele, A History of the Paper Publications Society (Labarre Foundation). (Amsterdam: Paper Publications Society, 1983).

108 "Inventory J 340, Piccard watermark collection," u Hauptstaatsarchiv Stuttgart, pristupljeno 1. rujna 2021., https://www.piccard-online.de/einfueh.php?sprache=en.

${ }^{109}$ International Association of Paper Historians, "International Standard for the Registration of Papers With or Without Watermarks: Version 2.1.1" (International Association of Paper Historians, 2013).
} 
je od Austrijske akademije za znanost, koja je i danas koordinator projekta Bernstein. ${ }^{110}$

Cilj projekta Bernstein bio je stvoriti integrirano europsko digitalno okruženje koje obuhvaća povijest rada i znanje o papiru. Projekt je povezao sve zainteresirane europske baze podataka vodenih znakova, ${ }^{111}$ čime je pružio sveobuhvatan i autoritativni izvor informacija o papiru. Baza podataka imala je koristi od specijaliziranih modula za tumačenje vodenih znakova i širokoga raspona kontekstualnih podataka koji sadrže bibliografski i geografski (GIS) sadržaj. Rezultat je Bernstein portal s 35 zbirki vodenih znakova i više od 246.500 vodenih znakova iz 16 država.

U Hrvatskoj danas još uvijek ne postoji nacionalna baza vodenih znakova, no postoje pojedini projekti u sklopu kojih se formiraju baze vodenih znakova. Tako možemo spomenuti projekt Digitalizacija, bibliografska obrada i istraživanje tekstova zadarsko-šibenskoga područja iz razdoblja do kraja 19. stoljeća pisanih glagoljicom, bosančicom i latinicom, u sklopu kojega je formiran i katalog vodenih znakova nađenih na papiru korištenom u kodeksima zadarskoga i šibenskoga područja. ${ }^{112}$ Korake prema formiranju baze vodenih znakova poduzele su u Hrvatskom državnom arhivu Suzana Njegač i Suzana Grubešić, predstavivši svoj rad 2021. godine na stručnom skupu Susreti konzervatora - restauratora arhivskog gradiva $i$ knjižnične grade te umjetnina na papiru. ${ }^{113}$

\section{Zaključak}

Poznavanje povijesti papira te načina njegove proizvodnje i kemijskoga sastava pomaže i njegovu razumijevanju, a to bitno određuje i izbor potrebnih konzervatorsko-restauratorskih radova. Valja imati u vidu kako neke od informacija nisu uvijek očigledne: poneke ćemo pronaći u samom papiru. Takve karakteristike otkrit će eventualna potrebna testiranja, kao što su ona za dokazivanje prisutnosti škroba ili lignina u papiru, ali i pregled papira na dnevnom svjetlu i uz pomoć pozadinskoga osvjetljenja. To će na vidjelo, među ostalim, iznijeti i prisutnost vodenih znakova (ako oni postoje), a koji nam pomažu u određivanju

\footnotetext{
${ }^{110}$ Ime projekta Bernstein dolazi od njemačke riječi za jantar. Projekt je sufinanciran od Europske komisije, eContentplus programa, od rujna 2006. do veljače 2009. godine.

${ }^{111}$ Partneri u projektu: International Paper Historians Association (IPH); Consortium of European Research Libraries; Archiv der Erzdiözese Salzburg, Austria; Institut Valencià de Conservació i Restauració de Béns Culturals, Spain; Generalitat de Catalunya, Department de Cultura, Barcelona, Spain; Museo del Tesoro del Duomo, Vercelli, Italy; State Historical Museum of Russia, Moscow, Russia; Archives de la Ville de Luxembourg.

112 "VoZnaZD," u Pisana baština: Portal digitalizirane hrvatske pisane baštine zadarsko-šibenskog područja, pristupljeno 17. lipnja 2021., https://pisanabastina.unizd.hr/?pc=i\&id=12781.

113 “Kalendar događanja," u Dubrovačke knjižnice, pristupljeno 17. lipnja 2021. https://www.dkd.hr/ kalendar-doga\%C4\%91anja/susreti-konzervatora-restauratora-u-organizaciji-znanstvene-knjiznice.
} 
njegove provenijencije, kao i moguće datacije. Stoga ne čudi kako baze vodenih znakova postaju bitan alat u rukama konzervatora restauratora i ostalih istraživača. Baš zbog spomenutih mogućnosti njihova korištenja u istraživačke svrhe, kao i umjetničkih, povijesnih i drugih vrijednosti koje vodeni znakovi posjeduju sami po sebi, baze vodenih znakova i njihovo istraživanje predstavljaju vrijedan doprinos znanosti. Iako u Hrvatskoj postoje projekti koji za cilj imaju stvaranje baze vodenih znakova, još uvijek ne postoji nacionalna baza vodenih znakova koja bi takve projekte, kao i rezultate njihovih istraživanja objedinila. Njezinim osnutkom zabilježeni bi podatci zasigurno bili pregledniji i dostupniji zainteresiranim istraživačima, a ujedno bi ti vodeni znakovi mogli biti uvršteni u međunarodne baze, kao što je ona zamišljena projektom Bernestein, čime bi njihovo istraživanje bilo olakšano i stranim znanstvenicima, istraživačima i zaljubljenicima u znanost.

\section{Literatura}

Alibaux, Henri. "Methode de travail de C. M. Briquet (avec Bibliographie d' ouvrages publies en France et en Belgique sur l'histoire du Papier et les Filigranes depuis 1907)." Monumenta chartae papyraceae historiam illustrantia: Collection of Works and Documents Illustrating the History of Paper, ur. F. Labarre. Hilversum, Holland: Paper Publications Society, 1952.

Barrett, Timothy i dr. "Paper Through Time: Nondestructive Analysis of 14th- Through 19th-Century Papers." The University of Iowa, 11. lipnja 2020. Pristupljeno 1. rujna 2021. http://paper.lib.uiowa.edu /index.php.

Barrett, Timothy, Mark Ormsby, Joseph B. Lang. " Non-Destructive Analysis of 14th-19th Century European Handmade Papers." Restaurator 37, br. 2 (2016): str. 93-135.

Barrow, William J. Permanence/Durability of the Book-VII. Physical and Chemical Properties of Book Papers, 1507-1949. Richmond, Virginia, Barrow Research Laboratory, 1974.

Bloom, Jonathan M. "Papermaking: The Historical Diffusion of an Ancient Technique." U Mobilities of Knowledge, ur. Heike Jöns, Peter Meusburger i Michael Heffernan, str. 51-66. Cham: Springer, 2017.

Brückle, Irene. "The Role of Alum in Historical Papermaking." The Abbey Newsletter 17, br. 4 (1993): str. 53-57.

Bull's Head And Mermaid: The History of Paper and Watermarks from the Middle Ages to the Modern Period, ur. Peter Rückert, Sandra Hodeček i Emanuel Wenger. Stuttgart: Hauptstaatsarchiv Stuttgart, 2009. 
Dąbrowski, Jozef. "Paper Manufacture in Central and Eastern Europe Before the Introduction of Paper-making Machines." Łodź, srpanj 2008. Pristupljeno 7. lipnja 2021. http://www.paperhistory.org/dabro.pdf.

Derrick, Michele R., Dusan C. Stulik, James M. Landry. Infrared Spectroscopy in Conservation Science. Los Angeles: Getty Conservation Institute, 1999.

Desnica, Vladan. "Instrumentalna analiza, uz istoimeni nastavni kolegij na Odsjeku za restauriranje i konzerviranje, umjetnina." Skripta, Akademija likovnih umjetnosti Sveučilišta u Zagrebu, 2012.

Garlick, Karen. "A Brief Review of the History of Sizing and Resizing Practices." The Book and Paper Group Annual 5 (1986): str. 94-107.

Ginneken-van de Kasteele, B. J. A History of the Paper Publications Society (Labarre Foundation). Amsterdam: Paper Publications Society, 1983.

Harris, Neil. Paper and Watermarks as Bibliographical Evidence. Lyon: Institut d'histoire du livre, 2017.

Hubbe, Martin A., Cindy Bowden. "Handmade Paper: A Review of Its History, Craft, and Science.” BioResources 4, br. 4 (2009): str. 1736-1792.

Hunter, Dard. Papermaking: The History and Technique of an Ancient Craft. New York: Dover Publications, 2014.

"Idrisi." U Hrvatska enciklopedija: 5: Hu-Km, ur. August Kovačec, str. 38. Zagreb: Leksikografski zavod Miroslav Krleža, 2003.

International Association of Paper Historians. "International Standard for the Registration of Papers With or Without Watermarks: Version 2.1.1." International Association of Paper Historians, 2013.

"Inventory J 340, Piccard watermark collection." U Hauptstaatsarchiv Stuttgart. Pristupljeno 1. rujna 2021. https://www.piccard-online.de/einfueh. php?sprache=en.

"Kalamus." U Hrvatska enciklopedija: 5: Hu-Km, ur. August Kovačec, str. 438. Zagreb: Leksikografski zavod Miroslav Krleža, 2003.

"Kalendar događanja." U Dubrovačke knjižnice. Pristupljeno 17. lipnja 2021. https://www.dkd.hr/kalendar-doga\%C4\%91anja/susreti-konzervatora-restauratora-u-organizaciji-znanstvene-knjiznice.

“Kodeks." U Hrvatska enciklopedija: 6: Kn-Mak, ur. August Kovačec, str. 22-23. Zagreb: Leksikografski zavod Miroslav Krleža, 2004.

Kos, J. "Papir." U Tehnička enciklopedija: 10: Oru-Polj, str. 127-146. Zagreb: Jugoslavenski leksikografski zavod, 1986.

Kulundžić, Zvonimir. Knjiga o knjizi: Historija pisama, materijala $i$ instrumenata za pisanje. Zagreb: Školska knjiga, 1951. 
“Maceracija." U Hrvatska enciklopedija: 6: Kn-Mak, ur. August Kovačec, str. 721. Zagreb: Leksikografski zavod Miroslav Krleža, 2004.

Mahgoub, Hend, Tiphaine Bardon, Dirk Lichtblau, Tom Fearn, Matija Strlič. "Material Properties of Islamic Paper." Heritage Science 4, br. članka 34 (studeni 2016). Pristupljeno 21. lipnja 2021. https://heritagesciencejournal. springeropen.com/articles/10.1186/s40494-016-0103-4.

Mesaroš, Franjo. Grafička enciklopedija. Zagreb: Tehnička knjiga, 1971.

Mošin, Vladimir. "Filigranologija kao pomoćna historijska nauka." Zbornik Odsjeka za povijesne znanosti Zavoda za povijesne i društvene znanosti Hrvatske akademije znanosti i umjetnosti 1 (1954): str. 25-93.

Njegač, Suzana, Andreja Dragojević. "Premazi pisanog, crtanog/slikanog i tiskanog gradiva na papiru i pergameni." U 21. seminar Arhivi, Knjižnice, Muzeji: Mogućnosti suradnje okruženju globalne informacijske strukture, ur. Mirna Willer i Ivana Prgin, str. 365-374. Zagreb: Hrvatsko arhivističko društvo, 2018.

"Papetterie." U Recueil de planches, sur les sciences, les arts liberaux, et les arts mechaniques, avec leur explication: Quatrieme livraison, 248 Planches, str. [581-611]. Paris: Briasson, 1767.

"Proizvodnja papira." U Wikiwand. Pristupljeno 26. siječnja 2021. https://www.wikiwand.com/hr/Proizvodnja_papira.

"Pust." U Hrvatska enciklopedija: 9: Pri-Sk, ur. Slaven Ravlić, str. 108. Zagreb: Leksikografski zavod Miroslav Krleža, 2007.

Stipčević, Aleksandar. Povijest knjige. Zagreb: Nakladni zavod Matice hrvatske, 1985.

“The Nuremberg Chronicle." U World Digital Library. Pristupljeno 30. listopada 2019. https://www.wdl.org/en/item/4108/.

“Turkestan.” U Hrvatska enciklopedija: 11: Tr-Ž, ur. Slaven Ravlić, str. 112. Zagreb: Leksikografski zavod Miroslav Krleža, 2009.

Vodopivec Tomažič, Jedert. "Valvasor's Glory of the Dutchy of Carniola, 1689, Vol. III: Comparative Analysis of Binding Structure and Paper." U Bookbindings: Theoretical Approaches and Practical Solutions, ur. Nataša Golob i Jedert Vodopivec, str. 227-250. Turnhout: Brepols, cop. 2017.

"VoZnaZD." U Pisana baština: Portal digitalizirane hrvatske pisane baštine zadarsko-šibenskog područja. Pristupljeno 17. lipnja 2021. https://pisanabastina. unizd.hr/?pc=i\&id=12781. 
Summary

\section{HANDMADE PAPER: ITS HISTORY, MANUFACTURING, FEATURES AND WATERMARKS}

The article briefly outlines the history of the handmade paper production, from its invention in China in $105 \mathrm{CE}$, its expansion through the Arab world and its arrival in Europe, to the end of the $18^{\text {th }}$ century when paper began to be manufactured by machines. The history of the handmade paper is a long and interesting one, since its first invention as a replacement for parchment which was a prevalent writing surface material until invention of the first machines for grinding the paper pulp. The paper technology's voyage through Asian countries via Arab countries to Europe had lasted 11 centuries and had gone through various technological changes. Some of those have been kept until today as part of the paper manufacturing tradition. After paper arrived in Europe the technology and raw material had been adjusted to local circumstances: linen rags began to be used as raw material, with gelatine as an addition. The technologies became more advanced, paper mills expanded and the demand for paper increased as the result of the invention of the printing press and rising book production. The paper also outlines the historical development of watermarks, from the oldest surviving simple ones from Cremona, Italy to the more complex ones that gradually appeared as the result of the technological advancement. Paper watermark collectors and their collecting passion are responsible for the development of the new auxiliary historical science i.e. filigranology. Today entire digital platforms across Europe are dedicated to this part of paper history, registering their appearance that can help in dating the paper and sometimes even documents.

Keywords: paper; handmade paper production; properties of handmade paper; watermark; countermark; watermark databases 